ORIGINAL ARTICLE

\title{
A six year follow up study of the subclinical effects of carbon disulphide exposure on the cardiovascular system
}

\author{
T Takebayashi, Y Nishiwaki, T Uemura, H Nakashima, T Nomiyama, H Sakurai, K Omae
}

Occup Environ Med 2004;61:127-134. doi: 10.1136/oem.2002.006858

See end of article for authors' affiliations

Correspondence to: Dr T Takebayashi, Department of Preventive Medicine and Public Health, School of Medicine, Keio University, 35 Shinanomachi, Shinjuku-ku, Tokyo 1608582, Japan; Hake@ sc.itc.keio.ac.jp

Accepted 11 March 2003

\begin{abstract}
Aims: A six year prospective cohort study was conducted to clarify whether the current carbon disulphide $\left(\mathrm{CS}_{2}\right)$ exposure level is low enough to prevent subclinical health impairment and/or to ameliorate health effects due to previous high exposure. This paper describes the effects on the cardiovascular systems. Methods: The study subjects were 432 male workers exposed to $\mathrm{CS}_{2}$ and 402 non-exposed workers in Japan, all of whom were examined in 1992-93. A total of $251 \mathrm{CS}_{2}$ exposed, 140 formerly exposed, and 359 non-exposed workers participated in the follow up survey (follow up rate 89.9\%) in 1998-99. Mean duration of exposure was 19.3 years at the end the study. Mean $\mathrm{CS}_{2}$ and 2-thiothiazolidine-4-carboxylic acid (TTCA) concentrations were $5.0 \mathrm{ppm}$ and $1.6 \mathrm{mg} / \mathrm{g}$ creatinine. Health items examined were serum biochemical indices including lipids and coagulation-fibrinolysis factors, blood pressure, aortic stiffness, ophthalmography, and electrocardiography at rest and after Master's double 2 step test. Potential confounding factors were adjusted for.

Results: Incidence of ischaemic findings, defined as Minnesota codes I, IV $\mathrm{V}_{-3}, \mathrm{~V}_{1-3}$ (at rest and after the load), or receiving treatment for ischaemia, was significantly higher in the exposed workers, especially for the spinning/refining workers (adjusted OR $2.1 ; 95 \% \mathrm{Cl} 1.1$ to 4.0 ) or the highest quartile of six year mean TTCA (adjusted OR 3.9; $95 \% \mathrm{Cl} 1.8$ to 8.7), although the observed increase in risk was diminished when rigorous ECG criteria were applied. Incidence of retinal microaneurysm was increased with marginal significance. Among cardiovascular risk factors we examined, only blood pressure values were significantly increased in the exposed workers.

Conclusions: Increased risk of ischaemic electrocardiogram findings among Japanese viscose rayon workers was observed. Although its clinical significance is to be discussed, the current Japanese occupational exposure limit for $\mathrm{CS}_{2}, 10$ ppm, would be high to prevent subclinical cardiovascular effects in this study population.
\end{abstract}

A large body of evidence has documented the adverse effects of occupational exposure to carbon disulphide $\left(\mathrm{CS}_{2}\right.$, CAS no. 75-15-0) on multiple organs. The cardiovascular and nervous systems are considered to be the principal targets affected by $\mathrm{CS}_{2}$ exposure. ${ }^{2}$ Currently, the Japan Society for Occupational Health ${ }^{3}$ and the American Conference of Governmental Industrial Hygienists ${ }^{4}$ recommend a time weighted average (TWA) of $10 \mathrm{ppm}$ as the allowable occupational exposure limit for $\mathrm{CS}_{2}$, whereas the Deutsche Forschungsgemeinschaft ${ }^{5}$ of Germany reduced its MAK value to $5 \mathrm{ppm}$ as the TWA concentration. It remains to be clarified whether the current $\mathrm{CS}_{2}$ exposure level is low enough to prevent the occurrence of $\mathrm{CS}_{2}$ related health impairments and/or to ameliorate health effects due to previous high exposure.

Various researchers have investigated and reported $\mathrm{CS}_{2}$ effects on the cardiovascular system using mortality data ${ }^{6-9}$ and subclinical indicators of cardiovascular functions or their risk factors. ${ }^{10-13}$ Some studies showed a positive association between $\mathrm{CS}_{2}$ exposure and outcome indices measured, while others did not. This discrepancy may be explained by differences in $\mathrm{CS}_{2}$ exposure (intensity, duration) as well as differences in ethnic background, but a big issue to be solved is that most of the epidemiological studies in recent years were cross-sectional ones, ${ }^{14}$ in which temporal association could not be guaranteed, and therefore it is difficult to conclude whether a causal relation exists at a relatively low concentration of $\mathrm{CS}_{2}$.

We initiated a prospective cohort study with all Japanese rayon factories using sensitive indicators of subclinical health changes and detailed exposure assessment in 1992. ${ }^{15}{ }^{16}$ Study subjects' health was examined comprehensively, including cardiovascular, cerebrovascular, ophthalmological, neurological, neurobehavioural, and endocrinological aspects. In this paper, the results of $\mathrm{CS}_{2}$ effects on the cardiovascular system, including ophthalmography after six years follow up will be presented.

\section{SUBJECTS AND METHODS}

Study base, follow up, and exposure assessment The study design, results of follow up, and exposure assessment for six years were described previously. ${ }^{15-17}$ Briefly, the baseline survey was done in 1992-93 at 11 rayon manufacturing factories in Japan. The study subjects were 432 male workers exposed to $\mathrm{CS}_{2}$ and 402 male non-exposed workers from the same factories who had not been exposed to hazardous chemicals. In 1998 and 1999, the follow up survey was conducted and 750 subjects participated. The follow up rates were $89.9 \%$ in total, and $90.5 \%$ for the exposed and $89.3 \%$ for the non-exposed groups, respectively. None of the subjects had any medical history of cardiovascular diseases, including ischaemic heart diseases and hypertension with medical treatment at baseline, which we determined by checking companies' medical records and

Abbreviations: ECG, electrocardiography; LDL, low density lipoprotein; $\mathrm{HDL}$, high density lipoprotein; Lp(a), lipoprotein a; OR, odds ratio; PWV, pulse wave velocity; TTCA, 2-thiothiazolidine-4-carboxylic acid; TWA, time weighted average 


\section{Main messages}

- This is a six year prospective cohort study of all Japanese viscose rayon factories, with detailed exposure assessment for $\mathrm{CS}_{2}$ and sensitive indicators of subclinical cardiovascular effects.

- There is an association between exposure to $\mathrm{CS}_{2}$ and increase in incidence of ischaemic findings defined as Minnesota codes with overall exposure levels for six years of $5 \mathrm{ppm}\left(\mathrm{CS}_{2}\right)$ and $1.6 \mathrm{mg} / \mathrm{g}$ creatinine (TTCA).

- However, the observed increase in risk for ischaemic changes is diminished when rigorous ECG criteria are applied.

- There is some evidence that not only exposure prior to the study but also exposure during the observation period has some significant impact on ischaemic findings, although its degree of contribution is unknown.

- A marginally significant increase is observed in incidence of retinal microaneurysm, but there are no exposure related changes in various risk factors of arteriosclerosis except for blood pressure.

through a self administered questionnaire. Among the workers exposed to $\mathrm{CS}_{2}, 25 \mathrm{l}$ continued to be exposed to $\mathrm{CS}_{2}$ until the end of the study $\left(\mathrm{CS}_{2}\right.$ workers), but 140 workers were transferred to non- $\mathrm{CS}_{2}$ jobs (ex- $\mathrm{CS}_{2}$ workers), largely because three of the factories discontinued the production of rayon fibres during the study period between 1994 and 1995 due to changes in business circumstances. After the subjects' job records were summarised, some of the ex-CS 2 and the non-exposed workers were reclassified as $\mathrm{CS}_{2}$ workers because they were still being exposed to $\mathrm{CS}_{2}$ when they worked near the rayon production area; some non-exposed workers were excluded from the analysis because they had a history of $\mathrm{CS}_{2}$ exposure for 1-8 years prior to the observation period. In this paper, the total number of subjects analysed statistically was $744\left(\mathrm{CS}_{2}\right.$ exposed workers, 259; ex-CS workers, 133; and non-exposed workers, 352). Details of the follow up are described elsewhere. ${ }^{17}$

As all health examinations were not carried out on the same day, some subjects missed a few items depending on their work schedule. Table 1 presents a description of the demographic characteristics of the subjects at the time of the baseline survey and a summary of exposure assessment during the observation period. The frequencies of tobacco smokers and alcohol drinkers were slightly higher in the $\mathrm{CS}_{2}$ workers, but no statistically significant differences were noted among the three groups. During the observation period, $1.6 \%\left(\mathrm{CS}_{2}\right), 7.9 \%\left(\mathrm{ex}-\mathrm{CS}_{2}\right)$, and $7.1 \%$ (non-exposed) of the smokers had quit smoking; the frequency of smokers at the time of the follow up survey was as follows: $\mathrm{CS}_{2}$ workers, $69.0 \%$; ex- $\mathrm{CS}_{2}$ workers, $61.7 \%$; and non-exposed workers, 55.6\%. For exposure assessment, we measured urinary 2-thiothiazolidine-4-carboxylic acid (TTCA) adjusted with creatinine level as the internal exposure index from 1992, and eight hour time weighted average $\mathrm{CS}_{2}$ concentration in the breathing zone as the external exposure index from 1993 for each worker.

\section{Risk factors for cardiovascular diseases}

Blood biochemical indices examined were total cholesterol, HDL cholesterol, LDL cholesterol, apolipoprotein A-I, apolipoprotein B, lipoprotein a $(\mathrm{Lp}(\mathrm{a}))$ (follow up survey only), triglycerides, fibrinogen, tissue plasminogen activator,

\section{Policy implications}

- Re-evaluation of the current allowable occupational exposure limit for $\mathrm{CS}_{2}$ may be required, while the clinical significance of the risk indicators should be discussed since the observed effects in this population are subclinical and their sizes are small.

D-dimer, plasminogen activator inhibitor-1, and thrombinantithrombin complex III. The subjects were asked to fast at least 12 hours before blood collection at the time of the follow up survey, while only non-fasting blood collection was performed at the time of the baseline survey. The samples were sent to a nationwide clinical laboratory within 24 hours and analysed with standard methods. Determination of LDL cholesterol and $\operatorname{Lp}(\mathrm{a})$ was done only at the follow up survey. The laboratory ran internal and external quality control programs to minimise measurement variation.

\section{Subclinical indicator for vascular effect}

All of the examinations and diagnoses described in the following sections were done under blind conditions in terms of subjects' exposure status. Blood pressure was measured by a doctor with a sphygmomanometer in an air conditioned room after a 15 minute rest. Aortic stiffness was evaluated by measuring carotid-femoral pulse wave velocity (PWV) (PWV200, Fukuda Electric). Ultrasound measurement of the stiffness of the carotid artery was also done to obtain blood flow rate, maximal velocity of the blood, and stiffness parameter (QMF-2000XA, Hayashi-Denki Co). For the ophthalmography, a qualified doctor evaluated colour photo prints of ocular funds of both eyes for microaneurysm or retinal bleeding. Due to poor quality of an ophthalmograph, 33 subjects in the $\mathrm{CS}_{2}$ exposed group, 54 in the ex- $\mathrm{CS}_{2}$ group, and 82 in the non-exposed group were excluded from the statistical analysis for the follow up survey.

The exclusion occurred without relation to their exposure status or their ophthalmological findings because both examination and evaluation processes were performed under blind conditions. Since some of those had an ophthalmograph with good quality in the baseline survey, we compared the baseline prevalence of ophthalmological findings among them to explore the impact of such exclusion on the study results. The numbers of the subjects analysed here were 31 for the $\mathrm{CS}_{2}$ exposed group, 42 for the ex- $\mathrm{CS}_{2}$ group, and 45 for the non-exposed group.

\section{Electrocardiography (ECG) and related symptoms}

A 12-lead ECG at rest and after Master's double 2 step test were performed at both baseline and follow up surveys by an industrial physician or by our research team in the case when no industrial physician was available. ECG findings were evaluated by two cardiologists and coded according to Minnesota code $1982^{18}$ under blind conditions. Codes I, IV $\mathrm{V}_{1-3}$, $\mathrm{V}_{1-3}$ at rest and after the load (in the original coding rule, these correspond to $\mathrm{XI}_{1-3}$ and $\mathrm{XII}_{1-3}$ ) were considered as ischaemic signs, codes VI and VII were considered as conduction disturbance, and code VIII was considered as arrhythmia. If any subjects had medical treatment during the observation period, they were also considered to have positive findings. To take the clinical significance into account, we employed rigorous criteria for ischaemia, defined as any ECG changes (abnormal Q wave, QS pattern with complete bundle branch block, horizontal ST depression $\geqslant 2 \mathrm{~mm}$, ST increase with reciprocal ST depression, and negative T wave 
Table 1 Baseline characteristics of the study subjects and results of exposure assessment

\begin{tabular}{|c|c|c|c|}
\hline & Non-exposed workers & Ex- $\mathrm{CS}_{2}$ workers & $\mathrm{CS}_{2}$ workers \\
\hline Number & 352 & 133 & 259 \\
\hline Age (y) & 34.6 & 35.9 & 34.7 \\
\hline$<35$ & $137(38.9 \%)$ & $43(32.3 \%)$ & $108(41.7 \%)$ \\
\hline $35-44$ & $162(46.0 \%)$ & $80(60.2 \%)$ & $126(48.6 \%)$ \\
\hline$\geqslant 45$ & $53(15.1 \%)$ & $10(7.5 \%)$ & $25(9.7 \%)$ \\
\hline \multicolumn{4}{|l|}{ Smoking } \\
\hline Never & $91(25.9 \%)$ & $27(20.3 \%)$ & $54(20.8 \%)$ \\
\hline Former & $43(12.2 \%)$ & $13(9.8 \%)$ & $22(8.5 \%)$ \\
\hline Current ( $<30$ cigareftes/day) & $152(43.2 \%)$ & $72(54.1 \%)$ & $139(53.7 \%)$ \\
\hline Current $(\geqslant 30$ cigarettes/day) & $66(18.8 \%)$ & $21(15.8 \%)$ & $44(17.0 \%)$ \\
\hline \multicolumn{4}{|l|}{ Alcohol drinking } \\
\hline Never or occasional & $46(13.1 \%)$ & $23(17.3 \%)$ & $39(15.1 \%)$ \\
\hline Habitual ( $<45 \mathrm{~g}$ ethanol/day) & $244(69.3 \%)$ & $90(67.7 \%)$ & $169(65.3 \%)$ \\
\hline Habitual ( $\geqslant 45 \mathrm{~g}$ ethanol $/$ day) & $62(17.6 \%)$ & $20(15.0 \%)$ & $51(19.7 \%)$ \\
\hline Body mass index $\left(\mathrm{kg} / \mathrm{m}^{2}\right)^{*}$ & $22.6(2.8)$ & $22.7(2.7)$ & $22.2(2.5)$ \\
\hline Education ( $\% \geqslant$ high school) & $71.3 \%$ & $62.4 \%$ & $63.7 \%$ \\
\hline Shift work (\% shift workers) & $88.6 \%$ & $79.7 \%$ & $87.6 \%$ \\
\hline Coronary prone behaviour pattern (\%) & $20.2 \%$ & $18.9 \%$ & $18.9 \%$ \\
\hline $\begin{array}{l}\mathrm{CS}_{2} \text { exposure duration prior to the } \\
\text { study (yr) } \neq\end{array}$ & - & $10.9(2.3)$ & $10.9(2.3)$ \\
\hline $\begin{array}{l}\mathrm{CS}_{2} \text { concentration over the study period } \\
(\mathrm{ppm}) \pm\end{array}$ & - & $2.9(1.8) \dagger$ & $5.0(1.8)$ \\
\hline $\begin{array}{l}\text { TTCA over the study period }(\mathrm{mg} / \mathrm{g} \\
\text { creatinine) } \ddagger\end{array}$ & - & $1.3(1.5) \dagger$ & $1.6(1.9)$ \\
\hline
\end{tabular}

with $\geqslant 50 \%$ of $\mathrm{R}$ amplitude or upright $\mathrm{QRS}$ ) or as receiving medical treatment for ischaemic heart disease during the observation period. The London School of Hygiene Cardiovascular Questionnaire for ischaemia and myocardial infarction (Rose's questionnaire) was also done. ${ }^{18}$ The coronary prone behaviour pattern was surveyed and determined through a self administered, brief Japanese type A behaviour pattern questionnaire. ${ }^{19}$

\section{Statistical analysis}

Exposure status was categorised into three groups $\left(\mathrm{CS}_{2}\right.$ workers, ex-CS2 workers, and non-exposed workers). To elucidate exposure-response relations, job title at baseline (that is, spinning/refining workers and other $\mathrm{CS}_{2}$ workers), was first used as a surrogate marker of exposure. Eighteen $\mathrm{CS}_{2}$ workers had been transferred to different $\mathrm{CS}_{2}$ jobs during the study period, and allocated to a new job category in the case that job transfer occurred more than one year before the follow up survey. Exclusion of such workers did not change the results by separate analysis. Then, with the index of internal exposure, the subjects were classified into four roughly equal groups according to quartiles determined by six year TTCA levels.

In the analysis, both exposure to $\mathrm{CS}_{2}$ during the observation period and previous exposure prior to the study were accounted for, although it seemed difficult to precisely separate out these two factors in the biological sense. First, we tested the differences between the exposed, ex-CS $\mathrm{C}_{2}$, and the non-exposed groups at baseline and at follow up, by which the effects of $\mathrm{CS}_{2}$ exposure for their entire exposure period were examined. We also evaluated the changes during the six year observation period. For continuous data, intraindividual change over the observation period, defined as subtracting a value at the baseline survey from a value at the follow up survey, was compared for all variables except for LDL cholesterol and $\operatorname{Lp}(\mathrm{a})$. Moreover, we compared the health outcomes at follow up by including baseline values as covariates, in which baseline differences would be controlled for. ${ }^{20}$ For binary data, incidences over the six year observation period were compared.

The normality of data distribution was examined, and an appropriate transformation was performed in order to obtain a normal distribution before the analysis for continuous data. Mean values of the variables were calculated and compared by analysis of variance followed by Dunnett's $t$ test (nonexposed as a referent group). For incidence and prevalence data, proportions were compared by the $\chi^{2}$ test or Fisher's exact method without any adjustment for the multiplicity of comparisons. To control for possible confounders simultaneously, multiple linear regression models were developed for the continuous outcome variables and multiple logistic regression models were developed for the binary outcome variables. Potential confounding factors included in the models were age $(<35,35-44, \geqslant 45$ years $)$, body mass index $\left(\mathrm{BMI}, \mathrm{kg} / \mathrm{m}^{2}\right.$ ), education level (junior high school, senior high school, or higher), smoking status (never, past, current $(<30, \geqslant 30$ cigarettes/day)), alcohol intake (never or occasional, habitual $(<45, \geqslant 45 \mathrm{~g}$ ethanol/day)), shift work (yes or no), and coronary prone behaviour pattern (yes or no) at baseline. Systolic blood pressure and HDL cholesterol at baseline were added for ophthalmography, arterial stiffness, and ECG.

The effectiveness of all constructed models in describing outcome variables was checked by residual and collinearity analysis. Inclusion/exclusion of systolic blood pressure as a covariate into the full model did not change an estimate of a regression coefficient significantly. For blood biochemical indices, inclusion or exclusion of the subjects who used lipid lowering agents did not change the results (lipid lowering agent users were excluded from the analysis of the blood indices in table 2).

Sixteen of $133(12.0 \%)$ ex-CS 2 workers and 15 of 352 $(4.3 \%)$ non-exposed workers were exposed to solvents other than $\mathrm{CS}_{2}$ during the study period, but none of those solvents showed any health risks with regard to the cardiovascular systems. Thus, we did not exclude such workers from the analysis. Some of the data were missing because of absence on the day of a research team visit or incompleteness of the questionnaire; both of these situations occurred without any relation to exposure status or health status. All $p$ values were two sided. A test for trend of calculated OR was conducted by including exposure as a continuous variable in the regression model for the exposed group only. All statistical analysis was performed using the SAS package (Cary, NC). 
Table 2 Effects of exposure to carbon disulphide on the risk factors of cardiovascular disease in the follow up survey

\begin{tabular}{|c|c|c|c|c|}
\hline & $\begin{array}{l}\text { Non-exposed } \\
\text { workers }\end{array}$ & $\begin{array}{l}\mathrm{Ex}-\mathrm{CS}_{2} \\
\text { workers }\end{array}$ & $\begin{array}{l}\mathrm{CS}_{2} \text { exposed } \\
\text { workers }\end{array}$ & $\begin{array}{l}\text { p value } \\
\text { (ANOVA) }\end{array}$ \\
\hline 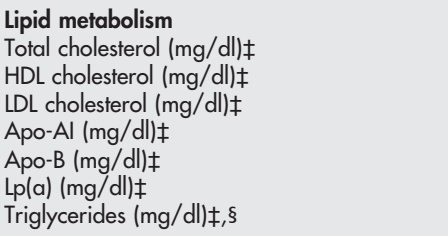 & $\begin{array}{l}(n=347) \\
195(1.2) \\
54(1.3) \\
119(1.3) \\
138(1.2) \\
97(1.3) \\
13(2.6) \\
108(1.7)\end{array}$ & $\begin{array}{l}(n=127) \\
193(1.2) \\
54(1.3) \\
117(1.3) \\
139(1.2) \\
96(1.3) \\
11(2.4) \\
104(1.8)\end{array}$ & $\begin{array}{l}(n=253) \\
198(1.2) \\
58(1.3)^{*} \\
118(1.3) \\
145(1.2)^{*} \\
97(1.3) \\
11(2.5) \\
102(1.8)\end{array}$ & $\begin{array}{l}0.32 \\
<0.01^{* *} \\
0.93 \\
<0.01 \text { ** } \\
0.87 \\
0.31 \\
0.50\end{array}$ \\
\hline $\begin{array}{l}\text { Coagulation-fibrinolysis system } \\
\text { Fibrinogen }(\mathrm{mg} / \mathrm{dl}) \ddagger \\
\text { Tissue plasminogen activator }(\mathrm{ng} / \mathrm{dl}) \ddagger \\
\text { D-dimer }(\mathrm{ng} / \mathrm{dl}) \ddagger \\
\text { Plasminogen activator inhibitor-1 }(\mathrm{ng} / \mathrm{dl}) \ddagger \\
\text { Thrombin-antithrombin complex III }(\mathrm{ng} / \mathrm{dl}) \ddagger\end{array}$ & $\begin{array}{l}(n=347) \\
241(1.2) \\
8(1.7) \\
50(1.4) \\
39(2.3) \\
2.2(3.5)\end{array}$ & $\begin{array}{l}(n=127) \\
244(1.2) \\
7(1.7) \\
52(1.6) \\
40(2.5) \\
1.8(3.2)\end{array}$ & $\begin{array}{l}(n=253) \\
240(1.3) \\
8(1.6) \\
50(1.5) \\
42(2.2) \\
2.4(3.1)\end{array}$ & $\begin{array}{l}0.69 \\
0.74 \\
0.65 \\
0.52 \\
0.16\end{array}$ \\
\hline $\begin{array}{l}\text { Blood pressure }(\mathrm{mm} \mathrm{Hg}) \\
\text { Systolic blood pressuref } \\
\text { Diastolic blood pressure }\end{array}$ & $\begin{array}{l}(n=336) \\
119(1.1) \\
71(1.2)\end{array}$ & $\begin{array}{l}(n=130) \\
118(1.1) \\
71(1.1)\end{array}$ & $\begin{array}{l}(n=250) \\
121(1.1) \\
73(1.2)\end{array}$ & $\begin{array}{l}0.05^{* *} \\
0.23\end{array}$ \\
\hline $\begin{array}{l}\text { Arterial stiffness } \\
\text { Aorta (pulse wave velocity, } \mathrm{m} / \mathrm{s}) \dagger \\
\text { Carotid artery (maximal blood flow, } \mathrm{cm} / \mathrm{s} \text { ) }\end{array}$ & $\begin{array}{l}(n=332) \\
6.8(0.9) \\
(n=325) \\
64.7(1.3)\end{array}$ & $\begin{array}{l}(n=129) \\
7.0(0.9) \\
(n=123) \\
61.4(1.2)\end{array}$ & $\begin{array}{l}(n=237) \\
6.6(0.9) \\
(n=240) \\
64.2(1.2)\end{array}$ & $\begin{array}{l}0.17 \\
0.08\end{array}$ \\
\hline $\begin{array}{l}\text { †Arithmetic mean (SD); Igeometric mean (C } \\
\text { §Subjects with non-fasting samples were excl } \\
\text { group, } 124 \text { for ex-CS } 2 \text { group, and } 321 \text { for } \\
{ }^{* *} p<0.05 \text { by ANOVA followed by Dunnett' }\end{array}$ & $\begin{array}{l}\text { hough inclusion } \\
\text { sposed group, } \\
{ }^{*} p<0.05 \mathrm{com}\end{array}$ & $\begin{array}{l}\text { of of those } \\
\text { respectiv } \\
\text { mpared to }\end{array}$ & d similar $r$ & $n=233$ for $C$ \\
\hline
\end{tabular}

\section{RESULTS \\ Effects on risk factors or subclinical indicators for cardiovascular diseases}

Table 2 shows the results of the measurement of blood biochemical indices in the follow up survey. For lipid metabolism, all items except HDL cholesterol and apolipoprotein A-I were comparable among the three groups. Prevalences of lipid lowering agent users at the time of the follow up survey were $4 / 259$ (1.5\%) among the $\mathrm{CS}_{2}$ workers, $5 / 133(3.8 \%)$ among the ex- $\mathrm{CS}_{2}$ workers, and $2 / 352(0.6 \%)$ among the non-exposed workers. When the multivariate analysis was applied, favourable increase of HDL cholesterol and apolipoprotein A-I remained significant, although we did not measure physical activity. For the coagulation-fibrinolysis system, there were no differences among the three groups at the time of follow up. Similar results were obtained for the baseline survey.

For blood pressure, $8 / 259$ (3.1\%) of the $\mathrm{CS}_{2}$ workers, $2 / 133$ (1.5\%) of the ex- $\mathrm{CS}_{2}$ workers, and $6 / 352(1.7 \%)$ of the nonexposed workers were under treatment for hypertension and were taking antihypertensive agents at the time of the follow up survey ( $p=0.43$ by $\chi^{2}$ test). Systolic blood pressure was small but significantly higher in the $\mathrm{CS}_{2}$ exposed group compared to the non-exposed group after controlling for possible confounders in the follow up survey (antihypertensive agent users were excluded from the analysis of blood pressure in table 2 ). With the multiple regression analysis, a regression coefficient for the $\mathrm{CS}_{2}$ group was 0.0103 (blood pressure value in $\mathrm{mm} \mathrm{Hg}$ as a dependent valuable was logarithmically transformed to obtain normality; 95\% CI 0.0029 to 0.0177 ), which indicates that systolic blood pressure of the $\mathrm{CS}_{2}$ workers was $2.4 \%$ higher compared to the non-exposed workers. Similar results were obtained for diastolic blood pressure. Its regression coefficient was 0.0097 (95\% CI 0.0007 to 0.0187 ), which is equivalent to a $2.3 \%$ increase for the exposed workers. In the baseline survey, geometric mean values of systolic/diastolic blood pressure were $121 / 70 \mathrm{~mm} \mathrm{Hg}$ for the $\mathrm{CS}_{2}, 120 / 69 \mathrm{~mm} \mathrm{Hg}$ for the ex$\mathrm{CS}_{2}$, and $119 / 69 \mathrm{~mm} \mathrm{Hg}$ for the non-exposed, respectively $(\mathrm{p}=0.40$ by ANOVA). With multiple regression analysis, the difference between the $\mathrm{CS}_{2}$ exposed and the non-exposed workers at baseline was small but statistically significant, while changes in systolic or diastolic pressures over six years were not statistically significant, when examined either by both intra-individual changes over six years or by comparison of blood pressure values at follow up with inclusion of a baseline value as a covariate. $\mathrm{CS}_{2}$ workers were divided into two groups according to their job type or four groups according to six year TTCA level to examine whether exposure dependent relations exist. We found that blood pressure levels were increased in some of the exposed groups, but exposure dependency was unclear. There were no differences for any of the indices of arterial stiffness in either the baseline survey or the follow up survey.

\section{Effects on ophthalmography and ECG}

Table 3 shows the prevalence at baseline and at follow up, and incidence during the six year observation period for retinal microaneurysm and ischaemic findings among the $\mathrm{CS}_{2}$ exposed, ex- $\mathrm{CS}_{2}$, and non-exposed groups. The prevalence of microaneurysm of the retinal artery was about two times higher in the exposed group compared to the nonexposed group at follow up as well as at baseline. The odds ratio (OR) of having a retinal microaneurysm among the unaffected subjects at baseline, that is, the incidence, was also marginally significant after controlling for various possible confounders. When the subjects were stratified by age, the incidence of the exposed groups was higher than that of the non-exposed group through all age strata, although no statistical significance was detected between the exposed and the non-exposed groups (table 4). Among those who were excluded from the statistical analysis for the follow up 
Table 3 Arteriosclerotic effects on the retinal artery and the coronary artery

\begin{tabular}{|c|c|c|c|c|}
\hline & $\begin{array}{l}\text { Non-exposed } \\
\text { workers }\end{array}$ & $\begin{array}{l}\text { Ex-CS } \\
\text { workers }\end{array}$ & $\begin{array}{l}\mathrm{CS}_{2} \text { exposed } \\
\text { workers }\end{array}$ & $p$ value \\
\hline \multicolumn{5}{|l|}{ Retinal microaneurysm } \\
\hline Prevalence (baseline) & $\begin{array}{l}16 / 277(5.8 \%) \\
1.0\end{array}$ & $\begin{array}{l}15 / 108(11.1 \%) \\
2.1(0.9-4.9)\end{array}$ & $\begin{array}{l}28 / 240(11.7 \%) \\
2.2(1.1-4.3)^{*}\end{array}$ & $0.04^{* *}$ \\
\hline Prevalence (follow up) & $\begin{array}{l}17 / 270(6.3 \%) \\
1.0\end{array}$ & $7 / 79(8.9 \%)$ & $\begin{array}{l}31 / 226(13.7 \%) \\
2.7(1.4-5.4)^{*}\end{array}$ & $0.02^{* *}$ \\
\hline Incidence over 6 years & $\begin{array}{l}11 / 219 \text { (5.0\%) } \\
1.0\end{array}$ & $\begin{array}{l}3 / 60(5.0 \%) \\
1.4(0.3-4.9)\end{array}$ & $\begin{array}{l}17 / 184(9.2 \%) \\
2.3(1.0-5.4)\end{array}$ & 0.20 \\
\hline \multicolumn{5}{|c|}{$1.0 \quad 1.4(0.3-4.9)$} \\
\hline \multicolumn{3}{|c|}{ Ischaemic signs (defined as Minnesota codes $\mathrm{I}_{1}, \mathrm{IV}_{1-3}, \mathrm{~V}_{1-3}$ or receiving treatment for ischaemia) } & $\begin{array}{l}\text { ent for ischaemia) } \\
3 / 258(1.2 \%)\end{array}$ & $0.02^{* *}$ \\
\hline Prevalence (follow up) & $\begin{array}{l}27 / 343(7.9 \%) \\
1.0\end{array}$ & $\begin{array}{l}7 / 130(5.4 \%) \\
0.7(0.3-1.7)\end{array}$ & $\begin{array}{l}32 / 257(12.5 \%) \\
1.7(0.9-3.1)\end{array}$ & $0.04^{* *}$ \\
\hline Incidence over 6 years & $\begin{array}{l}21 / 329(6.4 \%) \\
1.0\end{array}$ & $\begin{array}{l}6 / 129(4.7 \%) \\
0.7(0.3-1.9)\end{array}$ & $\begin{array}{l}30 / 254(11.8 \%) \\
2.0(1.1-3.6)^{*}\end{array}$ & $0.02^{* *}$ \\
\hline \multicolumn{5}{|c|}{ Ischaemia (defined as rigorous ECG findings such as ST depression $\geqslant 2 \mathrm{~mm}$ or receiving treatment) } \\
\hline Prevalence (baseline) & $\begin{array}{l}5 / 344(1.5 \%) \\
-\end{array}$ & $\begin{array}{l}0 / 130(0 \%) \\
-\end{array}$ & $\begin{array}{l}2 / 258(0.8 \%) \\
-\end{array}$ & 0.37 \\
\hline Prevalence (follow up) & $\begin{array}{l}13 / 343 \text { (3.8\%) } \\
1.0\end{array}$ & $\begin{array}{l}4 / 130(3.1 \%) \\
1.1(0.3-3.8)\end{array}$ & $\begin{array}{l}9 / 257(3.5 \%) \\
1.0(0.4-2.7)\end{array}$ & 0.93 \\
\hline Incidence over 6 years & $\begin{array}{l}12 / 338(3.6 \%) \\
1.0\end{array}$ & $\begin{array}{l}4 / 130(3.1 \%) \\
1.1(0.3-4.1)\end{array}$ & $\begin{array}{l}9 / 255(3.5 \%) \\
1.1(0.4-3.0)\end{array}$ & 0.97 \\
\hline \multicolumn{5}{|c|}{$\begin{array}{l}\text { Results expressed as prevalence or incidence, with adjusted odds ratios underneath. } \\
{ }^{* *} \mathrm{p}<0.05 \text { by } \chi^{2} \text { test or Fisher's exact method; }{ }^{*} \mathrm{p}<0.05 \text { compared to the non-exposed group by multiple logistic } \\
\text { regression analysis, in which age, body mass index, education level, smoking status, alcohol intake, shift work, } \\
\text { coronary prone behaviour pattern, systolic blood pressure, and HDL cholesterol at baseline and exposure variable } \\
\text { were included as covariates. } \\
\text { Denominators are different because some of the subjects missed an ECG due to their work schedule or some were } \\
\text { excluded from the analysis due to quality of an ophthalmograph (see text for details). }\end{array}$} \\
\hline
\end{tabular}

survey, the baseline prevalences of ophthalmological findings were $3 / 31(9.7 \%)$ for the $\mathrm{CS}_{2}$ exposed group, $5 / 42$ (11.9\%) for the ex- $\mathrm{CS}_{2}$ group, and $4 / 45(8.9 \%)$ for the non-exposed group, respectively.

With regard to the arteriosclerotic effect of carbon disulphide on the coronary artery, the results vary depending on the criteria of ECG. When ischaemic signs were defined as Minnesota codes I, $\mathrm{IV}_{1-3}, \mathrm{~V}_{1-3}$ (at rest and after the load) or receiving treatment for ischaemia, its incidence over the observation period was significantly higher in the $\mathrm{CS}_{2}$ exposed group (11.8\%) compared to the non-exposed group $(6.4 \%)$ (table 3$)$. In contrast, when more rigorous criteria were employed, both incidence and prevalence were comparable among the three groups. When the subjects were stratified by age, the incidence of the exposed groups was higher than that of the non-exposed group through all age strata, although there was no clear age related increase in incidence (table 4). A non-significant increase in the incidence of the exposed workers was observed in the $\geqslant 45$ years of age stratum $(24.0 \%)$, while statistically significant increase was observed in the $<35$ years of age stratum $(12.4 \%)$. The latter finding was coincident with a higher mean TTCA and $\mathrm{CS}_{2}$ concentration in this age stratum. Two subjects for the exposed group and another two for the ex$\mathrm{CS}_{2}$ group were receiving medical treatment for ischaemic heart disease at the time of the follow up survey.

The prevalences of having symptoms for angina or possible myocardial infarction (Rose's questionnaire) were 16/259

Table 4 Age at baseline, exposure level, and incidence of retinal microaneurysm and ischaemic findings $\dagger$

\begin{tabular}{|c|c|c|c|c|c|}
\hline & \multicolumn{3}{|l|}{ Exposure index $\ddagger$} & \multicolumn{2}{|l|}{ Incidence } \\
\hline & $\begin{array}{l}\text { Exposure duration } \\
\text { prior to the study } \\
\text { (y) }\end{array}$ & $\begin{array}{l}\text { TTCA (mg/g } \\
\text { creatinine) }\end{array}$ & $\mathrm{CS}_{2}$ (ppm) & $\begin{array}{l}\text { Non-exposed } \\
\text { workers }\end{array}$ & $\begin{array}{l}\mathrm{CS}_{2} \text { exposed } \\
\text { workers }\end{array}$ \\
\hline \multicolumn{6}{|l|}{ Retinal microaneurysm } \\
\hline $\begin{array}{l}\text { Entire group } \\
\text { Age at baseline }\end{array}$ & $10.7(2.3)$ & $1.5(1.9)$ & $4.8(1.8)$ & $11 / 219(5.0 \%)$ & $17 / 184(9.2 \%)$ \\
\hline$<35$ & $6.1(2.1)$ & $1.9(2.0)$ & $6.0(1.7)$ & $5 / 78(6.4 \%)$ & $7 / 79(8.9 \%)$ \\
\hline $35-44$ & $16.0(1.8)$ & $1.3(1.9)$ & $4.0(1.8)$ & $3 / 99(3.0 \%)$ & $8 / 87(9.2 \%)$ \\
\hline$\geqslant 45$ & $19.4(1.6)$ & $1.4(1.9)$ & 4.1 (1.9) & $3 / 42$ (7.1\%) & $2 / 18(11.1 \%)$ \\
\hline \multicolumn{6}{|l|}{ Ischaemic findings $†$} \\
\hline $\begin{array}{l}\text { Entire group } \\
\text { Age at baseline }\end{array}$ & $10.8(2.3)$ & $1.6(1.9)$ & $5.0(1.8)$ & $21 / 329(6.4 \%)$ & $30 / 254(11.8 \%)^{*}$ \\
\hline$<35$ & $5.7(2.1)$ & $1.9(1.9)$ & $6.0(1.7)$ & $5 / 131(3.8 \%)$ & $13 / 105(12.4 \%)^{*}$ \\
\hline $35-44$ & $16.5(1.7)$ & $1.4(1.9)$ & $4.3(1.8)$ & $10 / 150(6.7 \%)$ & $11 / 124(8.9 \%)$ \\
\hline$\geqslant 45$ & $20.1(1.5)$ & $1.5(1.9)$ & $4.7(2.0)$ & $6 / 48(12.5 \%)$ & $6 / 25(24.0 \%)$ \\
\hline
\end{tabular}

†Defined as Minnesota codes $I, I V_{1-3}, V_{1-3}$ or receiving treatment for ischaemia ‡Geometric mean (GSD).

${ }^{*} \mathrm{p}<0.05$ compared to the non-exposed workers by $\chi^{2}$ test or Fisher's exact method. 
(6.2\%) of the $\mathrm{CS}_{2}$ workers, $12 / 132(9.1 \%)$ of the ex- $\mathrm{CS}_{2}$ workers, and $34 / 347(9.8 \%)$ of the non-exposed workers at the time of the follow up survey $\left(p=0.27\right.$ by $\chi^{2}$ test). In addition, the prevalence and incidence of ECG findings for conduction disturbance and arrhythmia were also comparable; for example, the prevalences for conduction disturbance and arrhythmia at the time of the follow up survey were $7 /$ $257(2.7 \%)$ and $2 / 257(0.8 \%)$ for the $\mathrm{CS}_{2}$ workers, $2 / 130$ $(1.5 \%)$ and $3 / 130(2.3 \%)$ for the ex- $\mathrm{CS}_{2}$ workers, and $10 / 343$ $(2.9 \%)$ and $9 / 343(2.6 \%)$ for the non-exposed workers, respectively.

To explore the exposure-response relation, we classified the exposed subjects according to their job title at baseline or to their internal exposure level over the study period, and their incidences were compared (table 5). Ischaemic findings were defined as Minnesota codes $\mathrm{I}_{1} \mathrm{IV}_{1-3}, \mathrm{~V}_{1-3}$ at rest or after the load or receiving treatment for ischaemia in this analysis. The overall OR as well as the OR for the highest quartile of six year TTCA were significantly increased for both ischaemic signs and retinal microaneurysm after controlling for age, although no significant regression coefficient was obtained by the test for trend. These relations remained significant when we accounted for various possible confounders simultaneously. The subjects in the high group had higher $\mathrm{CS}_{2}$ exposure during the study period, but their exposure duration was shorter with younger age.

\section{DISCUSSION}

Effects of occupational exposure to $\mathrm{CS}_{2}$ on the cardiovascular systems have been reported by various authors from different countries. ${ }^{911}{ }^{13} 3^{21-26}$ Recently, Sulsky et al reported the results of comprehensive review of the epidemiological studies for the possibility of cardiovascular effects of $\mathrm{CS}_{2}$ and pointed out that mixed, inconsistent results were found for the association between $\mathrm{CS}_{2}$ exposure and coronary heart disease or its indicators. ${ }^{14}$ Our study offers the opportunity to evaluate the statistical association between $\mathrm{CS}_{2}$ exposure and subclinical changes in various indices of the cardiovascular system because this is a cohort study with a high follow up rate (approx. 90\%) and because various risk factors of the cardiovascular diseases were evaluated and controlled for. We found a statistical association between $\mathrm{CS}_{2}$ exposure and subclinical ischaemic findings, defined by the Minnesota code, with a risk increase that was two times higher after controlling for major confounders among the Japanese rayon manufacturing workers. During the observation period, we undertook a detailed exposure assessment for all study subjects twice a year; their overall exposure levels to $\mathrm{CS}_{2}$ for six years were $5.0 \mathrm{ppm}\left(\mathrm{CS}_{2}\right.$ personal air sampling) and $1.6 \mathrm{mg} / \mathrm{g}$ creatinine (urinary TTCA as internal exposure index). When the $\mathrm{CS}_{2}$ exposed workers were divided into two or four groups according to their job titles or level of internal exposure, significant increases in the incidence were found for the spinning/refining workers $\left(6.1 \mathrm{ppm}\right.$ for $\mathrm{CS}_{2}$ and $2.0 \mathrm{mg} / \mathrm{g}$ creatinine for TTCA) or the highest quartile of the exposure ( $8.7 \mathrm{ppm}$ and $3.6 \mathrm{mg} / \mathrm{g}$ creatinine), although there was no linear increasing trend of the risk. It should be noted that the observed increase in risk of ischaemic findings was diminished when rigorous ECG criteria were applied.

The biological mechanisms by which $\mathrm{CS}_{2}$ induces toxic effects on the cardiovascular system have been proposed and investigated in experimental animals ${ }^{127-31}$ as well as in humans. ${ }^{112-34}$ In this study, we examined various risk indicators of arteriosclerosis such as serum lipid or the coagulation-fibrinolysis system, but there were no exposure related changes among these except blood pressure. This is consistent with the study in Taiwan in which increased ECG abnormality was observed while serum lipids levels were nearly identical to the reference group. ${ }^{24}$ Kotseva also reported the results of a cross sectional study in Belgium in which the prevalence of ischaemic ECG findings was significantly higher among the exposed workers whose cumulative exposure index was $150 \mathrm{mg} / \mathrm{m}^{3}$-year or more without any exposure related changes in blood pressure or

Table 5 Incidence of retinal microaneurysm and ischaemic findings $†$ with relation to job title or six year internal exposure level

\begin{tabular}{|c|c|c|c|c|c|c|c|}
\hline & \multicolumn{3}{|c|}{ Exposure index $\S$} & \multicolumn{2}{|l|}{ Incidence } & \multicolumn{2}{|l|}{ Odds ratioł } \\
\hline & $\begin{array}{l}\text { Exposure } \\
\text { duration prior } \\
\text { to the study ly }\end{array}$ & $\begin{array}{l}\text { TTCA (mg/g } \\
\text { creatinine) }\end{array}$ & $\mathrm{CS}_{2}$ (ppm) & $\begin{array}{l}\text { Non-exposed } \\
\text { workers }\end{array}$ & $\begin{array}{l}\mathrm{CS}_{2} \text { exposed } \\
\text { workers }\end{array}$ & Age adjusted & $\begin{array}{l}\text { Age }+ \text { other possible } \\
\text { confounders } \\
\text { adjusted }\end{array}$ \\
\hline \multicolumn{8}{|l|}{ Retinal microaneurysm } \\
\hline \multicolumn{8}{|l|}{ By job title at baseline } \\
\hline Other than spinning/refining & $9.9(2.2)$ & $0.9(1.8)$ & $2.8(1.8)$ & & $5 / 51(9.8 \%)$ & $2.2(0.7-6.6)$ & $3.2(0.9-10.3)$ \\
\hline Spinning or refining & $11.0(2.3)$ & $1.9(1.8)$ & $5.9(1.6)$ & & $12 / 133(9.0 \%)$ & $1.9(0.8-4.6)$ & $1.9(0.8-4.8)$ \\
\hline \multicolumn{8}{|c|}{ By internal exposure level for 1992-98 } \\
\hline Low & $11.1(2.2)$ & $0.6(1.4)$ & $2.4(1.7)$ & & $3 / 45(6.7 \%)$ & $1.4(0.4-5.3)$ & $1.9(0.5-7.4)$ \\
\hline Mid-low & $12.1(2.0)$ & $1.3(1.2)$ & $4.4(1.6)$ & & $5 / 46(10.9 \%)$ & $2.5(0.8-7.5)$ & $2.8(0.9-8.9)$ \\
\hline Mid-high & $12.1(2.5)$ & $1.9(1.1)$ & $5.9(1.3)$ & & $2 / 46(4.3 \%)$ & $0.9(0.2-4.2)$ & $0.5(0.1-4.3)$ \\
\hline $\begin{array}{l}\text { High } \\
\text { Ischaemic findings }\end{array}$ & $8.3(2.3)$ & $3.5(1.3)$ & $8.3(1.3)$ & & $7 / 46(15.2 \%)$ & $3.7(1.2-10.6)^{*}$ & $3.8(1.2-11.4)^{*}$ \\
\hline $\begin{array}{l}\text { Entire group } \\
\text { By job title at baseline }\end{array}$ & $10.8(2.3)$ & $1.6(1.9)$ & $5.0(1.8)$ & $21 / 329(6.4 \%)$ & $30 / 254(11.8 \%)$ & $2.1(1.2-3.8)^{*}$ & $2.1(1.1-4.0)^{*}$ \\
\hline Other than spinning/refining & $10.6(2.2)$ & $0.9(1.8)$ & $3.0(1.8)$ & & $8 / 74(10.8 \%)$ & $2.0(0.8-4.8)$ & $2.1(0.9-5.4)$ \\
\hline Spinning or refining & $10.9(2.3)$ & $2.0(1.8)$ & $6.1(1.7)$ & & $22 / 180(12.2 \%)$ & $2.1(1.1-4.0)^{*}$ & $2.1(1.1-4.1)^{*}$ \\
\hline \multicolumn{8}{|c|}{ By internal exposure level for $1992-98$} \\
\hline Low & $10.9(2.2)$ & $0.6(1.5)$ & $2.4(1.7)$ & & $8 / 63(12.7 \%)$ & $2.2(0.9-5.4)$ & $2.3(0.9-5.6)$ \\
\hline Mid-low & $12.4(2.0)$ & $1.3(1.2)$ & $4.6(1.5)$ & & $4 / 63(6.3 \%)$ & $1.1(0.4-3.4)$ & $1.0(0.3-3.1)$ \\
\hline Mid-high & $11.9(2.3)$ & $2.1(1.1)$ & $6.4(1.4)$ & & $6 / 65(9.2 \%)$ & $1.5(0.6-3.9)$ & $1.6(0.6-4.4)$ \\
\hline High & $8.6(2.5)$ & $3.6(1.3)$ & $8.7(1.3)$ & & $12 / 63(19.0 \%)$ & $3.9(1.8-8.7)^{*}$ & $4.2(1.8-9.7)^{*}$ \\
\hline \multicolumn{8}{|c|}{$\begin{array}{l}\text { †Defined as Minnesota codes } \mathrm{I}, \mathrm{IV} \mathrm{V}_{1-3}, \mathrm{~V}_{1-3} \text { or receiving treatment for ischaemia. } \\
\text { †OR for the non-exposed group was } 1.0 \text { as the referent. } \\
\text { TAdjusted for age, BMI, education level, smoking status, alcohol drinking, shift work, coronary prone behaviour pattern, systolic blood pressure, and HDL } \\
\text { cholesterol at baseline. } \\
\S \text { Geometric mean (SD). } \\
\text { " } \mathrm{p}<0.05 \text { compared to the non-exposed group by multiple logistic regression analysis, in which age, body mass index, education level, smoking status, alcohol } \\
\text { intake, shift work, coronary prone behaviour pattern, systolic blood pressure, and HDL cholesterol at baseline and exposure variable were included as covariates. }\end{array}$} \\
\hline
\end{tabular}


blood lipids. ${ }^{34}$ Drexler et al found no relation between $\mathrm{CS}_{2}$ exposure and various coronary risk factors including serum lipids, fibrinolytic activity, and electrolytes among German workers (median $\mathrm{CS}_{2}$ exposure level and exposure duration were $4.0 \mathrm{ppm}$ and 5.5 years, respectively) by a cross sectional design, and no effect of $\mathrm{CS}_{2}$ exposure on ECG findings was detected..$^{235}$

The only significant change we observed was a small increase in systolic and diastolic blood pressure in the exposed workers both at baseline and follow up surveys. However, if we combine the $\mathrm{CS}_{2}$ exposed workers with the ex- $\mathrm{CS}_{2}$ workers (ex-CS $\mathrm{S}_{2}$ workers were being exposed to $\mathrm{CS}_{2}$ at the time of the baseline survey), the differences at baseline between the combined $\mathrm{CS}_{2}$ exposed and ex- $\mathrm{CS}_{2}$ group and the non-exposed group were no more statistically significant, although blood pressure values were still slightly higher for the combined group. This indicates that blood pressure levels at baseline of the ex- $\mathrm{CS}_{2}$ workers from the closed-down factories were to some extent lower than those of the $\mathrm{CS}_{2}$ workers from the remaining factories. As this discontinuation of exposure among ex-CS $\mathrm{CS}_{2}$ workers was mostly due to changes in business policies of some of the participating companies, such selection was not health related, and could be by chance. Although the impact of $\mathrm{CS}_{2}$ exposure over the six year observation period on blood pressure may not be substantial because six year intra-individual changes in blood pressure levels or comparison of blood pressure levels at follow up with inclusion of a baseline value as a covariate did not show significant differences, increase of blood pressure due to $\mathrm{CS}_{2}$ exposure before the study period could relate to the increased risk of ischaemic findings in some degree, even if the difference was small. The biological plausibility of $\mathrm{CS}_{2}$ toxicity on the cardiovascular system should be investigated further.

The major limitation of our study is a lack of information on the exposure that occurred before the study period. Generally, exposure concentrations to hazardous chemicals have tended to be improved by the introduction of effective industrial hygienic control measures in occupational settings. Such a downward trend of exposure was observed in this population even during the study period, as shown in our previous paper. ${ }^{17}$ The most important question is whether the increased risk we observed was caused by the past exposure or by the recent exposure. One possible explanation for the observed association is that a higher exposure concentration of $\mathrm{CS}_{2}$ before the observation period had strong effects on the cardiovascular systems of the exposed workers, and its progression by the normal aging process without relation to low level $\mathrm{CS}_{2}$ exposure during the study period manifested itself in the increased risk of ischaemic findings. Unfortunately, we cannot know whether this is the case, but we performed additional analyses in order to assess the contribution of exposure over the observation period.

First, the exposed subjects were restricted to those whose exposure duration at baseline was less than five years and whose age at baseline was 20-44 $(\mathrm{n}=62)$. The same number of subjects from the referent group was randomly selected from the non-exposed group with the frequencies of five year age category matched. Although the number of subjects analysed was not enough to reach statistical significance, incidences of ischaemic findings defined by Minnesota codes were $14.5 \%$ for the $\mathrm{CS}_{2}$ exposed subjects and $4.8 \%$ for the non-exposed subjects ( $\mathrm{p}=0.13$ by Fisher's exact method). Geometric means of $\mathrm{CS}_{2}$ and TTCA during the observation period were $5.6 \mathrm{ppm}$ and $1.7 \mathrm{mg} / \mathrm{g}$ creatinine, respectively. This may reflect the result in table 4 showing that the significant increase in ischaemic incidence in the exposed workers was coincident with a higher mean TTCA and $\mathrm{CS}_{2}$ concentration in the $\leqslant 35$ years of age stratum where mean exposure duration was 5.7 years. Alternatively, we can compare the $\mathrm{CS}_{2}$ exposed workers with the ex-CS $\mathrm{C}_{2}$ workers. Since mean age and exposure duration at the time when the study began were comparable between them, an observed difference could be a sign of $\mathrm{CS}_{2}$ effects for the past six years. As already shown in table 3 , the incidence of ischaemic signs was higher in the $\mathrm{CS}_{2}$ workers than that in the ex- $\mathrm{CS}_{2}$ workers $(11.8 \% \vee 4.7 \%)$. When we directly compared the incidence of exposed workers with that in the ex- $\mathrm{CS}_{2}$ workers who had been transferred to non- $\mathrm{CS}_{2}$ jobs at least three years before the study ended, $110 \mathrm{ex}-\mathrm{CS}_{2}$ subjects were identified. The incidence for the ex- $\mathrm{CS}_{2}$ group was $4.5 \%$, and OR adjusted for age, systolic blood pressure, HDL cholesterol, and other possible confounders was $2.7(\mathrm{p}=0.052)$. These results indicate that not only the past exposure but also recent exposure had some significant impact on increased risk of ischaemic findings in this population, although its degree of contribution is unknown.

For ophthalmological effects, we obtained similar results as in our baseline report. ${ }^{15}$ One important result here is that incidence over the observation period for the exposed workers was increased with marginal significance compared to the non-exposed workers, while that for the ex- $\mathrm{CS}_{2}$ group was comparable with the non-exposed group. Although incidence and severity of the effects of $\mathrm{CS}_{2}$ on the retinal artery have been reduced over time, ${ }^{15}$ development of retinal microaneurysm could relate not only to the aging process but also to exposure to $\mathrm{CS}_{2}$ under relatively low concentrations below $10 \mathrm{ppm}$. There are two studies evaluating the effect of exposure cessation on the ophthalmological findings. Sugimoto et al followed up 214 Japanese viscose rayon workers for five years. ${ }^{36}$ They indicated that progression of retinopathy occurred in both the still exposed workers and those who had been transferred to jobs where there was no exposure, but none of the transferred workers showed progression of retinopathy if their exposure duration was 10 years or less. De Rouck et al reported the results of a four year follow up study of $29 \mathrm{CS}_{2}$ exposed workers in Belgium. ${ }^{37}$ During the observation period, most of them were removed from $\mathrm{CS}_{2}$ exposure. Prevalence and severity of retinal microaneurysm and small haemorrhage increased among workers in the relatively high $\mathrm{CS}_{2}$ level area (at least $50 \mathrm{mg}$ / $\left.\mathrm{m}^{3}\right)$. Among workers at in areas of lower $\mathrm{CS}_{2}\left(<10 \mathrm{mg} / \mathrm{m}^{3}\right)$, prevalence was unchanged while the number of microaneurysms increased. Since both studies did not have a nonexposed group as referents, it is difficult to separate out the effect of aging from the effect of exposure to $\mathrm{CS}_{2}$. Since we did not show significant deterioration of the retinal microaneurysm among the ex- $\mathrm{CS}_{2}$ workers whose mean exposure duration was 15.6 years at the end of exposure, past exposure would not relate to the progression of retinal microaneurysm in our population if exposure stopped. It should be noted that the significant increase in ophthalmological findings we observed here might be distorted to some extent because exclusion rates were sizable and different across the groups, even though such exclusion occurred randomly.

Our study results must be interpreted with caution besides the past exposure. First, an accurate estimation of real exposure is not simple, and it was not simple during the observation period. As we stated in the previous paper, when the exposure level was represented by maximum $\mathrm{CS}_{2}$ and TTCA levels during a six year period for each subject (TTCA $\left.\max , \mathrm{CS}_{2} \max \right)$, the geometric means for those were $9.4 \mathrm{ppm}$ and $4.6 \mathrm{mg} / \mathrm{g}$ creatinine, respectively. ${ }^{17}$ Thus, the study subjects could have been exposed to $\mathrm{CS}_{2}$ at levels near to or higher than the Japanese occupational exposure limit level (10 ppm) under certain working conditions, even though the average exposure level was maintained below the current occupational exposure limit during the observation period. 
Naturally, we cannot exclude the possibility that unmeasured confounding factors may have distorted the results or that the statistical adjustment of modifying or confounding factors may be insufficient. Moreover, since the observed effects of $\mathrm{CS}_{2}$ in this population were subclinical and their sizes were small, the clinical significance of $\mathrm{CS}_{2}$ exposure should be discussed as part of the risk management process.

In conclusion, using a longitudinal design with various subclinical indicators and detailed exposure assessment, we observed an increased risk of ischaemic ECG findings among Japanese viscose rayon workers. Exposure to $\mathrm{CS}_{2}$ during the past six years was supposed to have some significant impact on the findings. Although our results may not be applicable to newly engaged workers and the clinical significance is to be discussed, the current Japanese occupational exposure limit, $10 \mathrm{ppm}$, would be high to prevent subclinical cardiovascular effects in this study population.

\section{ACKNOWLEDGEMENTS}

We thank all the stuff members of the participating factories and members of the Japanese Rayon Workers' Health Study Group for conducting and completing the study. This study was supported by the Japan Chemical Fiber Association.

\section{Authors' affiliations}

T Takebayashi, Y Nishiwaki, T Uemura, H Nakashima, T Nomiyama, K Omae, Department of Preventive Medicine and Public Health, School of Medicine, Keio University, Japan

H Sakurai, Occupational Health Research and Development Center, Japan Industrial Safety and Health Association, Japan

\section{REFERENCES}

1 Beauchamp RO Jr, Bus JS, Popp JA, et al. A critical review of the literature on carbon disulfide toxicity. Crit Rev Toxicol 1983;11:169-278.

2 World Health Organisation. Environmental health criteria: carbon disulfide. Geneva: World Health Organisation, 1979.

3 Japan Society for Occupational Health. Recommendation of occupational exposure limits (2001-2002). J Occup Health 2001;43:208-23.

4 American Conference of Governmental Industrial Hygienists. TLV s and BEIs. Cincinnati: ACGIH, 2002.

5 Deutsche Forschungsgemeinschaft. List of MAK and BAT values 2001. Weinheim: Wiley-VCH, 2001.

6 Tiller JR, Schilling RS, Morris JN. Occupational toxic factor in mortality from coronary heart disease. BMJ 1968;4:407-11.

7 Nurminen M, Hernberg S. Effects of intervention on the cardiovascular mortality of workers exposed to carbon disulphide: a 15 year follow up. Br J Ind Med 1985;42:32-5.

8 Sweetnam PM, Taylor SW, Elwood PC. Exposure to carbon disulphide and ischaemic heart disease in a viscose rayon factory. $\mathrm{Br} J$ Ind Med 1987;44:220-7.

9 MacMahon B, Monson RR. Mortality in the US rayon industry. J Occup Med 1988;30:698-705.

10 Kamal AA, Ahmed A, Saied K, et al. Quantitative evaluation of ECG components of workers exposed to carbon disulfide. Environ Health Perspect 1991;90:301-4.

11 Vanhoorne M, De Bacquer D, De Backer G. Epidemiological study of the cardiovascular effects of carbon disulphide. Int J Epidemiol 1992;21:745-52.

12 Drexler H, Ulm K, Hardt R, et al. Carbon disulphide. IV. Cardiovascular function in workers in the viscose industry. Int Arch Occup Environ Health 1996;69:27-32.
13 Kotseva K, Braeckman L, De Bacquer D, et al. Cardiovascular effects in viscose rayon workers exposed to carbon disulfide. Int J Occup Environ Health 2001; 7:7-13.

14 Sulsky S, Hooven F, Burch M, et al. Critical review of the epidemiological literature on the potential cardiovascular effects of occupational carbon disulfide exposure. Int Arch Occup Environ Health 2002;75:365-80.

15 Omae K, Takebayashi T, Nomiyama T, et al. Cross sectional observation of the effects of carbon disulphide on arteriosclerosis in rayon manufacturing workers. Occup Environ Med 1998;55:468-72.

16 Takebayashi T, Omae K, Ishizuka C, et al. Cross sectional observation of the effects of carbon disulphide on the nervous system, endocrine system, and subjective symptoms in rayon manufacturing workers. Occup Environ Med 1998;55:473-9.

17 Takebayashi T, Nishiwaki Y, Nomiyama T, et al. Lack of relationship between occupational exposure to carbon disulfide and endocrine dysfunction: a sixyear cohort study of the Japanese rayon workers. J Occup Health 2003;45:111-18.

18 Rose G, Blackburn H, Gillum R, et al. Cardiovascular survey methods, 2nd edn. Geneva: World Health Organisation, 1982.

19 Maeda S. A study on behavior pattern of patients with coronary heart diseases [in Japanese]. Shinshin-lgaku 1985;25:297-306.

20 Senn S. Baseline adjustment in longitudinal studies. In: Armitage P, Colton T, eds. Encyclopedia of biostatistics. Chichester: John Wiley \& Sons, 1998:253-7.

21 Tolonen $M$, Hernberg S, Nurminen $M$, et al. A follow-up study of coronary heart disease in viscose rayon workers exposed to carbon disulphide. $\mathrm{Br} J$ Ind Med 1975;32:1-10.

22 Sakurai H, Seki Y. Cohort study of the hypertensive effects of carbon disulfide in viscose rayon workers. Keio J Med 1977;26:223-33.

23 Lee E, Kim S, Kim H, et al. Carbon disulfide poisoning in Korea with social and historical background. J Occup Health 1996;38:155-61.

24 Kuo HW, Lai JS, Lin M, et al. Effects of exposure to carbon disulfide (CS2) on electrocardiographic features of ischemic heart disease among viscose rayon factory workers. Int Arch Occup Environ Health 1997;70:61-6.

25 Braeckman L, Kotseva K, Duprez D, et al. Vascular changes in workers exposed to carbon disulfide. Ann Acad Med Singapore 2001;30:475-80.

26 Bortkiewicz A, Gadzicka E, Szymczak W. Cardiovascular disturbances in workers exposed to carbon disulfide. Appl Occup Environ Hyg $2001 ; 16: 455-63$.

27 Davidson M, Feinleib M. Carbon disulfide poisoning: a review. Am Heart J 1972;83:100-14.

28 Cunningham VJ. Effects of a single exposure to carbon disulphide on the rate of urea production and on plasma free fatty acid and glucose concentrations in the rat. Br J Ind Med 1975;32:140-6.

29 Wronska-Nofer T, Szendzikowski S, Obrebska-Parke M. Influence of chronic carbon disulphide intoxication on the development of experimental atherosclerosis in rats. Br J Ind Med 1980;37:387-93.

30 Laurman W, Wronska-Nofer T. Serum lipid and lipoprotein-cholesterol in rats jointly exposed to carbon disulphide and ethanol. Med $\operatorname{Pr}$ 1986;37:337-41.

31 Lewis JG, Graham DG, Valentine WM, et al. Exposure of C57BL/6 mice to carbon disulfide induces early lesions of atherosclerosis and enhances arterial fatty deposits induced by a high fat diet. Toxicol Sci 1999;49:124-32.

32 Egeland GM, Burkhart GA, Schnorr TM, et al. Effects of exposure to carbon disulphide on low density lipoprotein cholesterol concentration and diastolic blood pressure. Br J Ind Med 1992;49:287-93.

33 Jian L, Hu D. Antioxidative stress response in workers exposed to carbon disulfide. Int Arch Occup Environ Health 2000;73:503-6.

34 Kotseva K. Occupational exposure to low concentrations of carbon disulfide as a risk factor for hypercholesterolaemia. Int Arch Occup Environ Health $2001 ; 74: 38-42$.

35 Drexler H, Ulm K, Hubmann M, et al. Carbon disulphide. III. Risk factors for coronary heart diseases in workers in the viscose industry. Int Arch Occup Environ Health 1995;67:243-52.

36 Sugimoto K, Goto S, Hotta R. Studies on chronic carbon disulfide poisoning. A 5-year follow-up study on retinopathy due to carbon disulfide. Int Arch Occup Environ Health 1976;37:233-48.

37 De Rouck A, De Laey JJ, Van Hoorne M, et al. Chronic carbon disulphide poisoning: a 4 year follow-up study of the ophthalmological signs. Int Ophthalmol 1986;9:17-27. 